\author{
Д. Л. Бондарєв
}

Дніпровсько-Орільський природний заповідник

\title{
СТРУКТУРА НЕРЕСТОВОї ПОПУЛЯЩЇ̈ ЛЯЩА (ABRAMIS BRAMA) ВОДОЙМ ДНІПРОВСЬКО-ОРІЛЬСЬКОГО ПРИРОДНОГО ЗАПОВІДНИКА
}

\begin{abstract}
Розглянуто стан популяції цінного промислового виду іхтіофауни Дніпровського водосховища - Abramis brama Linnaeus, 1758 на акваторії Дніпровсько-Орільського природного заповідника. Визначено основні популяційні характеристики виду у водоймах заповідника. Надано оцінку сучасному стану нерестової популяції та розглянуто перспективи подальшого існування ляща на акваторії заповідника.
\end{abstract}

The population state of important food fish Abramis brama L. in the Dniprovsko-Orelsky Nature Reserve is under consideration . Basic population parameters of the species have been studied. Assessment of modern state and determination of perspectives of further existence of the roach in the Reserve's basins have been done.

\section{Ветуп}

Враховуючи сучасний стан гідроекосистеми Дніпровського водосховища в режимі каскадності, а також умови формування його іхтіокомплексу під впливом низки факторів природного та антропогенного походження, вивчення стану популяцій фонових і ресурсних видів $є$ одним із головних напрямків іхтіологічних науково-дослідних робіт, що проводяться на його акваторії протягом останніх десятиліть [4;8].

Розташування акваторії Дніпровсько-Орільського природного заповідника в межах верхньої ділянки Дніпровського (Запорізького) водосховища, що зазнала максимальної антропогенної трансформації протягом останніх 60 років, обумовлює необхідність проведення комплексних іхтіологічних досліджень. Це необхідно для визначення напрямків і глибини процесів, що відбуваються під впливом дії сукупності антропогенних чинників, як у популяціях окремих видів риб, так і в існуючому іхтіокомплексі взагалі. Саме тому до пріоритетних напрямків діяльності заповідника відносяться не тільки збереження та відтворення іхтіофауни в його водоймах і на суміжних із ним акваторіях, а і проведення комплексних іхтіологічних досліджень, у тому числі і вивчення стану популяцій окремих видів риб у єдиному блоці моніторингових досліджень іхтіофауни на акваторії Дніпровського водосховища. Унаслідок значної трансформації літоралі правобережжя Дніпра та розташованих там природних нерестовищ, заплавні водойми заповідника (лівобережжя Дніпра) залишились майже єдиним місцем відтворення іхтіофауни в межах верхньої ділянки водосховища. Тут загальні трансформаційні процеси літоралі та постійна дія антропогенного впливу виражена мінімально. Це обумовлює значну цінність заплавних водойм як репродуктивного та нагульного центру для більшості видів риб, а також дозволяє використовувати акваторії заповідника як науковий полігон при проведенні комплексних іхтіологічних досліджень на Дніпровському водосховищі взагалі [1-3; 7].

Лящ - один із найважливіших ресурсних видів риб водойм України. Характеризується високими темпами росту та потенційною значимістю, як можливий пріоритетний промисловий вид відноситься до функціонально цінних видів водосховищ-

С Д. Л. Бондарєв, 2007

Вісник Дніпропетровського університету. Біологія, екологія. Vìsnik Dnìpropetrovs'kogo unìversitetu. Serîa Bìologiâ, ekologiâ Visnyk of Dnipropetrovsk University. Biology, ecology. Vìsn. Dnìpropetr. Unìv. Ser. Bìol. Ekol. 2007. 15(1).

ISSN 2310-0842 print ISSN 2312-301X online www.ecology.dp.ua 
них екосистем. За характером харчування лящ - типовий бентофаг, що споживає в основному “м’який” бентос. На акваторії Дніпровського водосховища він відноситься до категорії цінних ресурсних видів і є одним з основних об’єктів промислового та аматорського рибальства. Розповсюдженість і значна чисельність ляща, особливо на верхній ділянці, а також суттєва чутливість виду на дії антропогенних факторів дозволяють використовувати його як вид-індикатор при проведенні моніторингових іхтіологічних досліджень. Саме тому вивчення структурних показників популяції ляща дає змогу адекватно оцінити стан його популяції, виявити роль у структурі іхтіоценозу як водойм заповідника, так і суміжних акваторій, а також визначити загальний рівень навантаження на вид, оцінити реакцію популяції на умови існування в екосистемі Дніпровського водосховища [5].

\section{Матеріал і методи досліджень}

Враховуючи значну площу водойм заповідника (за даними лісовпорядкування 1991 року, їх загальна площа складає 680 га, тобто близько 30 \% территорії), вивчення стану іхтіофауни - один із пріоритетних напрямків моніторингових досліджень [1]. Матеріали, що склали основу роботи, зібрані на акваторії водойм заповідника у весняний період 2001-2004 років. Відбір проб проводили стандартним набором знарядь лову (ставні сітки з вічком від 30 до 90 мм) на різних ділянках водойм заповідника. Усі роботи, пов’язані з вилученням риб із природних водойм заповідника, проводили згідно $з$ діючими нормативами та інструкціями [9]. Для визначення базових параметрів популяції ляща під час досліджень вилучено та проаналізовано (на повний біологічний аналіз) 646 екземплярів риб. Обробку зібраного матеріалу здійснювали на базі лабораторії біомоніторингу НДІ біології ДНУ.

\section{Результати та їх обговорення}

Загальний віковий ряд популяції ляща у водоймах заповідника нараховує 12 вікових класів, у 2001 році відмічено 9 вікових класів, у 2002 та 2003 роках - 10, а в 2004 році - 11 вікових класів (табл. 1). Максимальний вік самців становить 910 років, а в 2003 році самців старше 8 років не зареєстровано. Старшовікові особини реєструвалися поодиноко (за винятком показників 2002 року). На відміну від самців, самки мають ширший віковий ряд. В усі роки постійно відмічалися самки віком до 10 років, а в окремі роки, але поодиноко, - до 13-річного віку.

Віковий ряд популяції ляща 3 водойм заповідника характеризується певною обмеженістю, особливо це стосується самців. Це може бути пов'язаним із елімінацією старшовікових класів популяції під впливом ряду факторів антропогенного характеру, у першу чергу - вилучення промисловим і аматорським рибальством. У контрольних іхтіологічних дослідженнях ставними знаряддями лову особини ляща відзначаються 3 дворічного віку, але слід зазначити, що у 2003 році група дворічного віку дослідженнями не відмічена.

На акваторії заповідника лящ починає нереститися 3 трирічного віку (статевозрілі особини складають до $10 \%$ загальної чисельності цієї вікової групи), відносна частка статевозрілих самців цього віку вища, ніж у самок. Ядро популяції ляща формують вікові класи 5-7 років, причому зі значним чисельним домінуванням. Їх загальна частка у популяції коливається від 61,4 (2001р.) до 74,5 \% (2003р.). Відповідно, частка інших класів, за винятком восьмирічних особин (3,5-13,5 \%), а також дев' ятирічних самок у 2003 році (12,8 \%) значно менша, а їх роль у загальному гомеостазі популяції мінімальна. Ці вікові групи суттєво не впливають на оптимізацію функціональних параметрів популяції, хоча їх репродуктивна роль

Вісник Дніпропетровського університету. Біологія, екологія.

Vìsnik Dnìpropetrovs'kogo unìversitetu. Serîa Bìologiâ, ekologiâ

Visnyk of Dnipropetrovsk University. Biology, ecology. Vìsn. Dnìpropetr. Unìv. Ser. Bìol. Ekol. 2007. 15(1).

ISSN 2310-0842 print ISSN 2312-301X online www.ecology.dp.ua 
максимальна. Частка класів, що вступає в репродуктивний вік (три- та чотирилітки) у нерестовій популяції незначна $-3,4-6,9 \%$ та 5,0-8,7 \% відповідно. Як виняток слід відзначити суттєву представленість групи триліток у 2001 році (12,9\%) та чотириліток у 2002 році $(20,1 \%)$. Це - наслідок сприятливих умов для відтворення ляща, що склалися на акваторіїі заповідника у 1998 році, й у подальшому мали позитивний вплив на загальний рівень поповнення популяції.

Вікова структура (\%) нерестової популяції ляща (Abramis brama)

Таблиия 1 Дніпровсько-Орільського природного заповідника (весна 2001-2004 років)

\begin{tabular}{|c|c|c|c|c|c|c|c|c|c|c|c|c|c|}
\hline \multirow{2}{*}{ Рік } & \multirow{2}{*}{ Стать } & \multicolumn{12}{|c|}{ Вік, роки } \\
\hline & & 2 & 3 & 4 & 5 & 6 & 7 & 8 & 9 & 10 & 11 & 12 & 13 \\
\hline \multirow{3}{*}{2001} & 우 & 4,69 & 10,94 & 4,69 & 17,18 & 17,18 & 21,88 & 12,5 & 7,81 & 3,13 & - & - & - \\
\hline & $0^{\pi}$ & 1,32 & 14,47 & 5,26 & 21,05 & 25,0 & 19,74 & 10,53 & 2,63 & - & - & - & - \\
\hline & $\phi+\sigma^{\lambda}$ & 2,86 & 12,85 & 5,0 & 19,29 & 21,43 & 20,71 & 11,43 & 5,0 & 1,43 & - & - & - \\
\hline \multirow{3}{*}{2002} & 우 & 4,92 & 8,19 & 16,39 & 26,23 & 18,03 & 11,48 & 6,56 & 1,64 & 4,92 & - & - & 1,64 \\
\hline & $\frac{T}{0}$ & 0,89 & 6,19 & 22,12 & 28,32 & 26,55 & 9,73 & 1,77 & 0,89 & 3,54 & - & - & - \\
\hline & $q+\hat{O}$ & 2,3 & 6,9 & 20,11 & 27,59 & 23,56 & 10,34 & 3,45 & 1,15 & 4,02 & - & - & 0,58 \\
\hline \multirow{3}{*}{2003} & $q$ & - & 2,13 & 8,51 & 19,15 & 23,4 & 19,15 & 6,38 & 12,77 & 4,25 & 2,13 & 2,13 & - \\
\hline & $\hat{0}$ & - & 3,92 & 8,82 & 29,41 & 38,24 & 12,75 & 6,86 & - & - & - & - & - \\
\hline & $\phi+\hat{O}$ & - & 3,36 & 8,72 & 26,17 & 33,56 & 14,77 & 6,71 & 4,03 & 1,34 & 0,67 & 0,67 & - \\
\hline \multirow{3}{*}{2004} & 우 & 1,22 & 8,54 & 6,09 & 18,29 & 21,95 & 18,29 & 9,76 & 9,76 & 1,22 & 1,22 & 3,66 & - \\
\hline & $\hat{0}$ & 2,14 & 1,43 & 5,0 & 33,57 & 26,43 & 14,29 & 15,71 & 1,43 & - & - & - & - \\
\hline & $\phi+\hat{0}$ & 1,81 & 4,05 & 5,41 & 27,93 & 24,77 & 15,77 & 13,51 & 4,5 & 0,45 & 0,45 & 1,35 & - \\
\hline
\end{tabular}

3 одного боку, така вікова структура популяції дозволить збільшити відтворювальний потенціал, 3 іншого - репродуктивне навантаження припадає на класи, що активно вилучаються рибальством на акваторії верхньої ділянки Дніпровського водосховища, і це може значно впливати на загальну чисельність нерестового угруповання. Слід відзначити, що за досліджуваний період урожайне покоління 1998 року чітко простежується від трирічних особин у 2001 році $(12,9 \%)$ до особин шестирічного віку у 2004 році $(24,8$ \%), з незначними коливаннями показників чисельності у популяції за роками. Отримані результати дещо відрізняються від попередніх досліджень 1970-1980-х років. У першу чергу це стосується зменшення загальної долі старшовікових особин у популяції та збільшення репродуктивного навантаження на модальні та, інколи, на впершенерестуючі вікові групи [6].

Відмінності статевої структури у популяції ляща виражають наступне. Частка самців у досліджуваній популяції значно вища, ніж самок (у 1,2-2,2 раза), і якщо у 2001 році цей показник близький до оптимуму, то в інші роки спостерігається певний дисбаланс статевої структури. Це може бути наслідком негативних природних процесів, що відбуваються на акваторії заповідника, а також низкою інших факторів, які обумовили низький рівень міграції самок на місця нересту.

У подальшому це може відобразитися на якості репродуктивного циклу та призвести до зниження потенціалу відтворення популяції ляща на зазначеній акваторії. Порівняно з самцями, віковий ряд самок більше розширений (відмічаються особини віком до 13 років). Найчисельніше в популяції представлені самки п'ятисемирічного віку $(55,7-61,7 \%$ загальної чисельності). В окремі роки спостерігається збільшення частки самок у вікових класах 8 та 9 років. Віковий ряд самців протягом усього періоду дослідження характеризується як скорочений. У нерестовій популяції максимально предсталені самці вікових груп 5-7 років, на долю яких припадає 64,6$80,4 \%$ загальної чисельності. Крім того, в окремі роки значну представленість у популяції мають дев'яти-, а також три- та чотирирічні самці.

Вісник Дніпропетровського університету. Біологія, екологія. Vìsnik Dnìpropetrovs'kogo unìversitetu. Seriâ Bìologiâ, ekologiâ Visnyk of Dnipropetrovsk University. Biology, ecology. Vìsn. Dnìpropetr. Unìv. Ser. Bìol. Ekol. 2007. 15(1).

ISSN 2310-0842 print ISSN 2312-301X online www.ecology.dp.ua 
Розмірно-вагові параметри дослідженої популяції ляща свідчать про наявність деяких негативних тенденцій. Це дозволяє визначити іiі стан як відмінний від оптимального (табл. 2). Темп лінійного росту ляща характеризується максимальними показниками у віці від 3 до 4 років, у період досягнення репродуктивної зрілості, річний приріст складає 8,0-12,8 см. Після цього ріст ляща дещо уповільнюється, стає стабільнішим і коливається, в основному, залежно від умов нагулу (як індивідуальних, так і обумовлених загальними продукційними процесами в екосистемі).

Таблиия 2

Розмірно-вагова структура нерестової популяції ляща (Abramis brama) Дніпровсько-Орільського природного заповідника (весна 2001-2004 років)

\begin{tabular}{|c|c|c|c|c|c|c|c|c|c|c|c|c|c|}
\hline \multirow{2}{*}{ Стать } & \multirow{2}{*}{$P$} & \multicolumn{12}{|c|}{ Вік, роки } \\
\hline & & 2 & 3 & 4 & 5 & 6 & 7 & 8 & 9 & 10 & 11 & 12 & 13 \\
\hline 1 & 2 & 3 & 4 & 5 & 6 & 7 & 8 & 9 & 10 & 11 & 12 & 13 & 14 \\
\hline \multicolumn{14}{|c|}{$2001 \mathrm{p}$} \\
\hline \multirow{3}{*}{ ㅇ } & $L$ & $\begin{array}{c}16,00 \pm \\
1,53\end{array}$ & $\begin{array}{c}19,57 \pm \\
1,17\end{array}$ & $\begin{array}{c}32,67 \pm \\
0,67\end{array}$ & $\begin{array}{c}30,82 \pm \\
1,67\end{array}$ & $\begin{array}{c}36,91 \pm \\
0,31\end{array}$ & \begin{tabular}{|c|}
$39,57 \pm$ \\
0,40
\end{tabular} & $\begin{array}{c}41,38 \pm \\
0,60\end{array}$ & $\begin{array}{c}45,20 \pm \\
1,62\end{array}$ & $\begin{array}{c}47,50 \pm \\
3,50\end{array}$ & - & - & - \\
\hline & $M$ & $\begin{array}{c}0,09 \pm \\
0,04\end{array}$ & $\begin{array}{c}0,18 \pm \\
0,03\end{array}$ & $\begin{array}{c}0,84 \pm \\
0,08\end{array}$ & $\begin{array}{c}0,71 \pm \\
0,10\end{array}$ & $\begin{array}{c}1,14 \pm \\
0,04\end{array}$ & $\begin{array}{c}1,37 \pm \\
0,06\end{array}$ & $\begin{array}{c}1,50 \pm \\
0,08\end{array}$ & $\begin{array}{c}1,88 \pm \\
0,18\end{array}$ & $\begin{array}{c}2,25 \pm \\
0,45\end{array}$ & - & - & - \\
\hline & $n$ & 3 & 7 & 3 & 11 & 11 & 14 & 8 & 5 & 2 & - & - & - \\
\hline \multirow{3}{*}{ 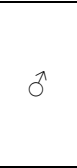 } & $L$ & 19,00 & $\begin{array}{c}20,09 \pm \\
1,04 \\
\end{array}$ & $\begin{array}{c}31,50 \pm \\
0,87 \\
\end{array}$ & $\begin{array}{c}33,81 \pm \\
0,69 \\
\end{array}$ & $\begin{array}{c}36,89 \pm \\
0,31 \\
\end{array}$ & \begin{tabular}{|c|}
$38,20 \pm$ \\
0,55 \\
\end{tabular} & $\begin{array}{c}43,38 \pm \\
0,78 \\
\end{array}$ & $\begin{array}{c}45,00 \pm \\
3,00 \\
\end{array}$ & - & - & - & - \\
\hline & $M$ & 0,17 & $\begin{array}{c}0,21 \pm \\
0,03\end{array}$ & $\begin{array}{c}0,68 \pm \\
0,06\end{array}$ & $\begin{array}{c}0,84 \pm \\
0,05\end{array}$ & $\begin{array}{c}1,05 \pm \\
0,03\end{array}$ & $\begin{array}{c}1,19 \pm \\
0,06\end{array}$ & $\begin{array}{c}1,60 \pm \\
0,08\end{array}$ & $\begin{array}{c}1,68 \pm \\
0,33\end{array}$ & - & - & - & - \\
\hline & $n$ & 1 & 11 & 4 & 16 & 19 & 15 & 8 & 2 & - & - & - & - \\
\hline \multirow{3}{*}{$q+\hat{\jmath}$} & $L$ & $\begin{array}{c}16,75 \pm \\
1,31 \\
\end{array}$ & $\begin{array}{c}19,89 \pm \\
0,76\end{array}$ & $\begin{array}{c}32,0 \pm \\
0,58\end{array}$ & $\begin{array}{c}32,59 \pm \\
0,83\end{array}$ & $\begin{array}{c}36,90 \pm \\
0,23\end{array}$ & $\begin{array}{c}38,86 \pm \\
0,36\end{array}$ & $\begin{array}{c}42,38 \pm \\
0,54\end{array}$ & $\begin{array}{c}45,14 \pm \\
1,30\end{array}$ & $\begin{array}{c}47,50 \pm \\
3,50\end{array}$ & - & - & - \\
\hline & $M$ & $\begin{array}{c}0,11 \pm \\
0,04\end{array}$ & $\begin{array}{c}0,20 \pm \\
0,02\end{array}$ & $\begin{array}{c}0,75 \pm \\
0,06\end{array}$ & $\begin{array}{c}0,79 \pm \\
0,05\end{array}$ & $\begin{array}{c}1,09 \pm \\
0,03\end{array}$ & $\begin{array}{c}1,28 \pm \\
0,04\end{array}$ & $\begin{array}{c}1,55 \pm \\
0,06\end{array}$ & $\begin{array}{c}1,82 \pm \\
0,15\end{array}$ & $\begin{array}{c}2,25 \pm \\
0,45 \\
\end{array}$ & - & - & - \\
\hline & $n$ & 4 & 18 & 7 & 27 & 30 & 29 & 16 & 7 & 2 & - & - & - \\
\hline \multicolumn{14}{|c|}{2002 p. } \\
\hline \multirow{3}{*}{ 우 } & $L$ & $\begin{array}{c}18,50 \pm \\
1,50 \\
\end{array}$ & $\begin{array}{c}22,17 \pm \\
0,65\end{array}$ & $\begin{array}{c}31,40 \pm \\
1,20 \\
\end{array}$ & $\begin{array}{c}34,33 \pm \\
0,30 \\
\end{array}$ & $\begin{array}{c}36,36 \pm \\
0,34\end{array}$ & $\begin{array}{c}40,86 \pm \\
0,63 \\
\end{array}$ & $\begin{array}{c}43,0 \pm \\
1,22\end{array}$ & 44,00 & $\begin{array}{c}48,33 \pm \\
0,33 \\
\end{array}$ & - & - & 52,00 \\
\hline & $M$ & $\begin{array}{c}0,13 \pm \\
0,02 \\
\end{array}$ & $\begin{array}{c}0,24 \pm \\
0,02 \\
\end{array}$ & $\begin{array}{c}0,80 \pm \\
0,09 \\
\end{array}$ & $\begin{array}{c}0,94 \pm \\
0,03 \\
\end{array}$ & $\begin{array}{c}1,06 \pm \\
0,03 \\
\end{array}$ & $\begin{array}{c}1,51 \pm \\
0,06 \\
\end{array}$ & $\begin{array}{c}1,75 \pm \\
0,19 \\
\end{array}$ & 1,92 & $\begin{array}{c}3,00 \pm \\
0,37 \\
\end{array}$ & - & - & 3,90 \\
\hline & $n$ & 2 & 6 & 10 & 15 & 11 & 7 & 4 & 1 & 3 & - & - & 1 \\
\hline \multirow{3}{*}{ 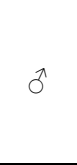 } & $L$ & 15.00 & $\begin{array}{c}24.00 \pm \\
1.05\end{array}$ & $\begin{array}{c}32.40 \pm \\
0.48\end{array}$ & $\begin{array}{c}34.31 \pm \\
0.16\end{array}$ & $\begin{array}{c}37.26 \pm \\
0.19\end{array}$ & \begin{tabular}{|c|}
$37.91 \pm$ \\
0.44
\end{tabular} & $\begin{array}{c}42.00 \pm \\
2.00\end{array}$ & 45.00 & $\begin{array}{c}46.50 \pm \\
0.87\end{array}$ & - & - & - \\
\hline & $M$ & 0.06 & $\begin{array}{c}0.32 \pm \\
0.04\end{array}$ & $\begin{array}{c}0.77 \pm \\
0.03\end{array}$ & $\begin{array}{c}0.92 \pm \\
0.03\end{array}$ & $\begin{array}{c}1.15 \pm \\
0.02\end{array}$ & $\begin{array}{l}1.23 \pm \\
0.05\end{array}$ & $\begin{array}{c}1.62 \pm \\
0.29\end{array}$ & 1.92 & $\begin{array}{c}2.18 \pm \\
0.05\end{array}$ & - & - & - \\
\hline & $n$ & 1 & 7 & 25 & 39 & 31 & 11 & 3 & 1 & 4 & - & - & - \\
\hline \multirow{3}{*}{$q+\hat{o}$} & $L$ & $\begin{array}{c}17.33 \pm \\
1.45 \\
\end{array}$ & $\begin{array}{c}23.15 \pm \\
0.67 \\
\end{array}$ & $\begin{array}{c}32.11 \pm \\
0.48 \\
\end{array}$ & $\begin{array}{c}34.31 \pm \\
0.14 \\
\end{array}$ & $\begin{array}{c}37.02 \pm \\
0.18 \\
\end{array}$ & \begin{tabular}{|c|}
$39.06 \pm$ \\
0.49 \\
\end{tabular} & $\begin{array}{c}42.57 \pm \\
1.02 \\
\end{array}$ & $\begin{array}{c}44.5 \pm \\
0.50 \\
\end{array}$ & $\begin{array}{c}47.29 \pm \\
0.61 \\
\end{array}$ & - & - & 52.00 \\
\hline & $M$ & $\begin{array}{c}0.11 \pm \\
0.03 \\
\end{array}$ & $\begin{array}{c}0.28 \pm \\
0.03 \\
\end{array}$ & $\begin{array}{c}0.78 \pm \\
0.03 \\
\end{array}$ & $\begin{array}{c}0.92 \pm \\
0.02 \\
\end{array}$ & $\begin{array}{c}1.13 \pm \\
0.02 \\
\end{array}$ & $\begin{array}{c}1.34 \pm \\
0.05 \\
\end{array}$ & $\begin{array}{c}1.69 \pm \\
0.15 \\
\end{array}$ & $\begin{array}{c}1.92 \pm \\
0.00 \\
\end{array}$ & $\begin{array}{c}2.53 \pm \\
0.22 \\
\end{array}$ & - & - & 3.90 \\
\hline & $n$ & 3 & 13 & 35 & 54 & 42 & 18 & 7 & 2 & 7 & - & - & 1 \\
\hline \multicolumn{14}{|c|}{2003 p. } \\
\hline \multirow{3}{*}{ 우 } & $L$ & - & 17,00 & $\begin{array}{c}28,25 \pm \\
1,89\end{array}$ & $\begin{array}{c}34,44 \pm \\
0,24\end{array}$ & $\begin{array}{c}37,00 \pm \\
0,41\end{array}$ & \begin{tabular}{|c|}
$39,22 \pm$ \\
0,57
\end{tabular} & $\begin{array}{c}42,00 \pm \\
0,58\end{array}$ & $\begin{array}{c}44,67 \pm \\
1,20\end{array}$ & $\begin{array}{c}44,50 \pm \\
2,50\end{array}$ & 54,00 & 51,00 & - \\
\hline & $M$ & - & 0,08 & $\begin{array}{c}0,57 \pm \\
0,14\end{array}$ & $\begin{array}{c}0,94 \pm \\
0,03\end{array}$ & $\begin{array}{c}1,06 \pm \\
0,05\end{array}$ & $\begin{array}{c}1,25 \pm \\
0,06\end{array}$ & $\begin{array}{c}1,61 \pm \\
0,14\end{array}$ & $\begin{array}{c}1,85 \pm \\
0,20\end{array}$ & $\begin{array}{c}1,69 \pm \\
0,37\end{array}$ & 3,10 & 2,50 & - \\
\hline & $n$ & - & 1 & 4 & 9 & 11 & 9 & 3 & 6 & 2 & 1 & 1 & - \\
\hline \multirow{3}{*}{ ठ } & $L$ & - & $\begin{array}{c}17,25 \pm \\
0,75 \\
\end{array}$ & $\begin{array}{c}30,11 \pm \\
1,32 \\
\end{array}$ & $\begin{array}{c}33,3 \pm \\
0,25 \\
\end{array}$ & $\begin{array}{c}36,38 \pm \\
0,26 \\
\end{array}$ & \begin{tabular}{|c|}
$37,23 \pm$ \\
0,94 \\
\end{tabular} & $\begin{array}{c}39,71 \pm \\
1,21 \\
\end{array}$ & - & - & - & - & - \\
\hline & $M$ & - & $\begin{array}{c}0,10 \pm \\
0,02 \\
\end{array}$ & $\begin{array}{c}0,60 \pm \\
0,05 \\
\end{array}$ & $\begin{array}{c}0,82 \pm \\
0,02 \\
\end{array}$ & $\begin{array}{c}1,01 \pm \\
0,02 \\
\end{array}$ & $\begin{array}{c}1,09 \pm \\
0,08 \\
\end{array}$ & $\begin{array}{c}1,31 \pm \\
0,12 \\
\end{array}$ & - & - & - & - & - \\
\hline & $n$ & - & 4 & 9 & 30 & 39 & 13 & 7 & - & - & - & - & - \\
\hline \multirow{3}{*}{$q+\hat{O}$} & $L$ & - & $\begin{array}{c}17,20 \pm \\
0,58\end{array}$ & $\begin{array}{c}29,54 \pm \\
1,07\end{array}$ & $\begin{array}{c}33,56 \pm \\
0,21 \\
\end{array}$ & $\begin{array}{c}36,54 \pm \\
0,22\end{array}$ & $\begin{array}{c}38,05 \pm \\
0,63\end{array}$ & $\begin{array}{c}40,40 \pm \\
0,91\end{array}$ & $\begin{array}{c}44,67 \pm \\
1,20 \\
\end{array}$ & $\begin{array}{c}44,5 \pm \\
2,50 \\
\end{array}$ & 54,00 & 51,00 & - \\
\hline & $M$ & - & $\begin{array}{c}0,09 \pm \\
0,02 \\
\end{array}$ & $\begin{array}{c}0,59 \pm \\
0,05 \\
\end{array}$ & $\begin{array}{c}0,84 \pm \\
0,02 \\
\end{array}$ & $\begin{array}{c}1,02 \pm \\
0,02 \\
\end{array}$ & $\begin{array}{c}1,16 \pm \\
0,06\end{array}$ & $\begin{array}{c}1,40 \pm \\
0,10\end{array}$ & $\begin{array}{c}1,85 \pm \\
0,20 \\
\end{array}$ & $\begin{array}{c}1,69 \pm \\
0,37 \\
\end{array}$ & 3,10 & 2,50 & - \\
\hline & $n$ & - & 5 & 13 & 39 & 50 & 22 & 10 & 6 & 2 & 1 & 1 & - \\
\hline
\end{tabular}


Закінчення табл. 2

\begin{tabular}{|c|c|c|c|c|c|c|c|c|c|c|c|c|c|}
\hline 1 & 2 & 3 & 4 & 5 & 6 & 7 & 8 & 9 & 10 & 11 & 12 & 13 & 14 \\
\hline \multicolumn{14}{|c|}{2004 p. } \\
\hline \multirow{3}{*}{ ㅇ } & $L$ & 17,00 & $\begin{array}{c}21,43 \pm \\
1,23\end{array}$ & $\begin{array}{c}32,60 \pm \\
1,60\end{array}$ & $\begin{array}{c}35,20 \pm \\
0,56\end{array}$ & $\begin{array}{c}37,83 \pm \\
0,50\end{array}$ & $\begin{array}{c}39,47 \pm \\
0,48\end{array}$ & $\begin{array}{c}39,63 \pm \\
1,29\end{array}$ & $\begin{array}{c}44,00 \pm \\
0,42\end{array}$ & 48,00 & 44,00 & $\begin{array}{c}52,67 \pm \\
1,67\end{array}$ & - \\
\hline & $M$ & 0,09 & $\begin{array}{c}0,20 \pm \\
0,04 \\
\end{array}$ & $\begin{array}{c}0,80 \pm \\
0,14 \\
\end{array}$ & $\begin{array}{c}1,05 \pm \\
0,05\end{array}$ & $\begin{array}{c}1,29 \pm \\
0,06\end{array}$ & $\begin{array}{c}1,48 \pm \\
0,07 \\
\end{array}$ & $\begin{array}{c}1,53 \pm \\
0,17\end{array}$ & $\begin{array}{c}2,02 \pm \\
0,08\end{array}$ & 2,60 & 1,86 & $\begin{array}{c}3,57 \pm \\
0,27\end{array}$ & - \\
\hline & $n$ & 1 & 7 & 5 & 15 & 18 & 15 & 8 & 8 & 1 & 1 & 3 & $\begin{array}{ll}- \\
-\end{array}$ \\
\hline \multirow{3}{*}{ 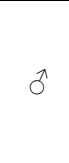 } & $L$ & $\begin{array}{c}17,33 \pm \\
1,20\end{array}$ & $\begin{array}{c}25,50 \pm \\
4,50\end{array}$ & $\begin{array}{c}33,43 \pm \\
0,43\end{array}$ & $\begin{array}{c}34,89 \pm \\
0,29\end{array}$ & $\begin{array}{c}36,22 \pm \\
0,42\end{array}$ & $\begin{array}{c}38,70 \pm \\
0,50\end{array}$ & $\begin{array}{c}41,00 \pm \\
0,55\end{array}$ & 45,00 & - & - & - & $\begin{array}{lll}- & \\
-\end{array}$ \\
\hline & $M$ & $\begin{array}{c}0,10 \pm \\
0,02 \\
\end{array}$ & $\begin{array}{c}0,42 \pm \\
0,22 \\
\end{array}$ & $\begin{array}{c}0,84 \pm \\
0,04\end{array}$ & $\begin{array}{c}0,94 \pm \\
0,03 \\
\end{array}$ & $\begin{array}{c}1,05 \pm \\
0,04 \\
\end{array}$ & $\begin{array}{c}1,25 \pm \\
0,05\end{array}$ & $\begin{array}{c}1,51 \pm \\
0,06\end{array}$ & $\begin{array}{c}1,93 \pm \\
0,13 \\
\end{array}$ & - & - & - & - \\
\hline & $n$ & 3 & 2 & 7 & 47 & 37 & 20 & 22 & 2 & - & - & - & $\begin{array}{lll}- & \\
-\end{array}$ \\
\hline \multirow{3}{*}{$q+\hat{O}$} & $L$ & $\begin{array}{c}17,25 \pm \\
0,85 \\
\end{array}$ & $\begin{array}{c}22,33 \pm \\
1,34\end{array}$ & $\begin{array}{c}33,08 \pm \\
0,68 \\
\end{array}$ & $\begin{array}{c}34,97 \pm \\
0,26\end{array}$ & $\begin{array}{c}36,75 \pm \\
0,34\end{array}$ & $\begin{array}{c}39,03 \pm \\
0,35 \\
\end{array}$ & $\begin{array}{c}40,63 \pm \\
0,53\end{array}$ & $\begin{array}{c}44,2 \pm \\
0,36\end{array}$ & 48,00 & 44,00 & $\begin{array}{c}52,67 \pm \\
1,67\end{array}$ & - \\
\hline & $M$ & $\begin{array}{c}0,10 \pm \\
0,01 \\
\end{array}$ & $\begin{array}{c}0,25 \pm \\
0,06 \\
\end{array}$ & $\begin{array}{c}0,82 \pm \\
0,06 \\
\end{array}$ & $\begin{array}{c}0,97 \pm \\
0,02 \\
\end{array}$ & $\begin{array}{c}1,13 \pm \\
0,03 \\
\end{array}$ & $\begin{array}{c}1,35 \pm \\
0,04 \\
\end{array}$ & $\begin{array}{c}1,51 \pm \\
0,06 \\
\end{array}$ & $\begin{array}{c}2,00 \pm \\
0,07 \\
\end{array}$ & 2,60 & 1,86 & $\begin{array}{c}3,57 \pm \\
0,27 \\
\end{array}$ & - \\
\hline & $n$ & 4 & 9 & 12 & 62 & 55 & 35 & 30 & 10 & 1 & 1 & 3 & - \\
\hline
\end{tabular}

Примітки: $P$ - показники вибірки, $L$ - середня довжина тіла (см), $M$ - середня маса (кг), $n$ - кількість екземплярів.

Це виражається не тільки в розмаху коливань усередині вікового угруповання залежно від статі, а й у змінах за роками. Слід зазначити, що річні розходження довжини тіла максимально виражені у групах ювенільних і вперше дозріваючих особин. Крім того, за темпами зростання розміру та ваги у вікових групах 2-4 роки значно виділяються самці. Хоча, звичайно, більшими розмірно-ваговими параметрами, починаючи 3 чотирирічного віку (досягнення статевої зрілості), характеризуються самки. У модальних і старшовікових групах темпи щорічного приросту розмірно-вагових параметрів виражені незначно, показники, в основному близькі один до одного. Як виняток, слід відзначити переважання лінійних розмірів самців у групі восьмидев'ятирічних особин у 2004 році. Але, взагалі, існуючі статеві відмінності показників лінійного росту не дозволяють виявити будь яку тенденцію та закономірність.

Показники зміни ваги, в основному, відповідають таким для лінійного росту, при наявності деяких особливостей. Маса тіла самиць, особливо статевозрілих, вища, ніж у самців. Але в молодших вікових групах (2-4 роки) відмічається переважання самців за ваговими показниками. Крім того, у деякі періоди в модальних класах також спостерігаються відхилення від норми (вікова група 5 років у 2001 та 6 років у 2002 р.). Ця особливість пояснюється тим, що молодші вікові класи представлені переважно ювенільними особинами 3 незрілими статевими продуктами (особливо самки), а маса тіла у статевозрілих самок вища, ніж у самців, за рахунок ваги гонад.

\section{Висновки}

1. Віковий ряд популяції ляща 3 водойм заповідника нараховує 12 класів. Максимальний вік самців становить 10 , самок - 13 років. Старшовікові особини (10 років i більше) зустрічаються одинично та нерегулярно. У цілому, популяція характеризується певною обмеженістю вікового ряду та мінімальною чисельністю старшовікових особин, що пов'язано з елімінацією старшовікових класів унаслідок дії ряду антропогенних факторів і, в першу чергу, рибальства.

2. Ядро популяції формують вікові класи 5-7 років, загальна доля яких коливається в межах 61,4-74,5 \%. Частка інших вікових класів значно нижча, але в окремі роки вони мають суттєву представленість. Така тенденція домінування спостерігається як у самок, так і у самців.

3. На акваторії заповідника лящ починає нерестувати з трирічного віку (статевозрілі особини складають до 10 \% загальної чисельності цієї вікової групи). Загальна представленість статевозрілих самців у цьому віці значно вища, ніж самок.

Вісник Дніпропетровського університету. Біологія, екологія. Vìsnik Dnìpropetrovs'kogo unìversitetu. Serîa Bìologîa, ekologìâ Visnyk of Dnipropetrovsk University. Biology, ecology. Vìsn. Dnìpropetr. Unìv. Ser. Bìol. Ekol. 2007. 15(1).

ISSN 2310-0842 print ISSN 2312-301X online www.ecology.dp.ua 
4. Частка самців у нерестовому угрупованні значно вища, ніж самок (у 1,22,2 раза). Лише в 2001 р. співвідношення самців і самок у популяції близьке до оптимуму. Це свідчить про певний дисбаланс статевої структури популяції, що може знизити іiі відтворювальний потенціал.

5. Аналіз розмірно-вагової структури популяції свідчить про сприятливі умови нагулу в акваторії заповідника. Розмірно-вагові показники ляща 3 водойм заповідника відповідають таким з інших акваторій Дніпровського водосховища.

6. Досліджені показники дозволяють визначити стан популяції ляща у водоймах заповідника як досить напружений, далекий від оптимального. Це обумовлено високим рівнем антропогенного навантаження на популяцію (особливо на модальні класи) у суміжних акваторіях, а також деформацією статевої структури нерестового угруповання під впливом негативних природних процесів, що відбуваються у заповіднику останнім часом. Разом із тим, усталені темпи лінійно-вагового приросту свідчать про досить сприятливі умови нагулу.

7. Для поліпшення загального стану популяції ляща у водоймах заповідника доцільно ввести обмеження на рибальство (промислове та аматорське) в охоронній зоні заповідника, що дасть змогу зменшити рівень навантаження на існуючу популяцію. Крім того, необхідно провести ряд гідромеліоративних заходів у пригирлових ділянках заплавних водойм, які могли б сприяти оптимізаціії стану популяцій у його акваторії.

\section{Бібліографічні посилання}

1. Бондарев Д. Л. Ихтиофауна водоемов Днепровско-Орельского заповедника: ретроспективный анализ и современное состояние / Д. Л. Бондарев, О. А. Христов, В. Н. Кочет // Вісник Дніпропетровського університету. Біологія. Екологія. - 2003. - Вип. 11, т. 1. - С. 13-20.

2. Бондарєв Д. Л. Фауна риб прибережної зони Дніпровсько-Орільського заповідника на сучасному етапі розвитку іхтіоценозу // Вісник Дніпропетровського університету. Біологія. Екологія. - 2004. - Вип. 12, т. 1. - С. 7-12.

3. Бондарєв Д. Л. Структура нерестової популяції плітки водойм Дніпровсько-Орільського природного заповідника // Вісник Дніпропетровського університету. Біологія. Екологія. 2006. - Вип. 14, т. 2. - С. 20-24.

4. Булахов В. Л. Іхтіологічні та рибогосподарські дослідження на Дніпровському водосховищі / В. Л. Булахов, Р. О. Новицький, О. О. Христов // Вісник Дніпропетровського університету. Біологія. Екологія. - 2003. - Вип. 11, т. 2. - С. 7-18.

5. Мельников Г. Б. О структуре популяций промысловых рыб Днепродзержинского и Днепровского водохранилищ / Г. Б. Мельников, В. Л. Булахов, С. Н. Цегер // Охрана рыбных запасов и увеличение продуктивности водоемов южной зоны СССР. Матер. межвуз. совещ. - Кишинев, 1970. - С. 181-183.

6. Тарасенко С. Н. Современное состояние рыбных запасов Запорожского водохранилища и пути их оптимизации / С. Н. Тарасенко, О. А. Христов // Экологические основы воспроизводства биологических ресурсов степного Приднепровья. - Д.: ДГУ, 1986. - С. 101-110.

7. Тарасенко С. Н. Заповедные акватории как репродуктивная основа оптимизации водохранилищных экосистем / С. Н. Тарасенко, О. А. Христов, С. Н. Ермилов // Актуальные проблемы охраны окружающей природной среды. - Запорожье, 1983. - С. 114-115.

8. Терещенко В. Г. Стратегия охраны рыбных ресурсов в новых экономических условиях водохранилищ // Вісник Дніпропетровського університету. Біологія. Екологія. - 2003. Вип. 11, т. 1. - С. 52-56.

9. Чугунова И. И. Методика изучения возраста и роста рыб. - М.: Изд-во АН СССР, 1952. - 175 с.

Надійшла до редколегї 03.12.2006

Вісник Дніпропетровського університету. Біологія, екологія.

Vìsnik Dnìpropetrovs'kogo unìversitetu. Serîa Bìologiâ, ekologiâ

Visnyk of Dnipropetrovsk University. Biology, ecology. Vìsn. Dnìpropetr. Unìv. Ser. Bìol. Ekol. 2007. 15(1).

ISSN 2310-0842 print ISSN 2312-301X online www.ecology.dp.ua 